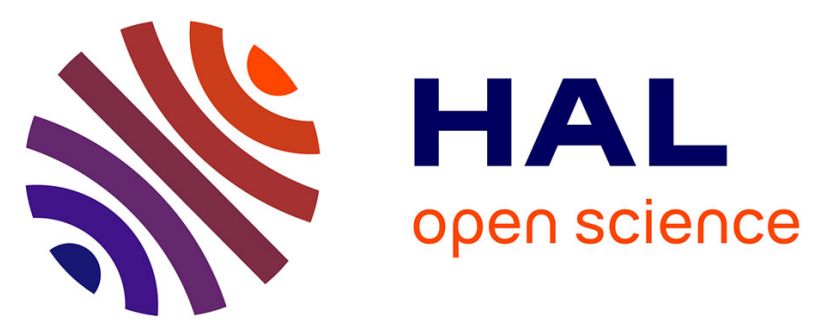

\title{
Natural attenuation of priority and emerging contaminants during river bank filtration and artificial recharge
}

\author{
A. Bruchet, S. Robert, M. Esperanza, M.L. Janex Habibi, Cecile Miege, \\ Marina Coquery, H. Budzinski, K. Lemenach
}

\section{To cite this version:}

A. Bruchet, S. Robert, M. Esperanza, M.L. Janex Habibi, Cecile Miege, et al.. Natural attenuation of priority and emerging contaminants during river bank filtration and artificial recharge. European journal of water quality - Journal européen d'hydrologie, 2011, 42 (2), p. 123 - p. 133. 10.1051/wqual/2012004 . hal-00757334

\section{HAL Id: hal-00757334 \\ https://hal.science/hal-00757334}

Submitted on 26 Nov 2012

HAL is a multi-disciplinary open access archive for the deposit and dissemination of scientific research documents, whether they are published or not. The documents may come from teaching and research institutions in France or abroad, or from public or private research centers.
L'archive ouverte pluridisciplinaire HAL, est destinée au dépôt et à la diffusion de documents scientifiques de niveau recherche, publiés ou non, émanant des établissements d'enseignement et de recherche français ou étrangers, des laboratoires publics ou privés. 


\title{
Natural attenuation of priority and emerging contaminants during river bank filtration and artificial recharge.
}

\author{
A.Bruchet*, S. Robert*, M. Esperanza*, M L.., Janex-Habibi*, C. Miège**, M. \\ Coquery**, H. Budzinski***, K. leMenach***
}

\author{
*CIRSEE, Suez-Environment, 38 rue du président Wilson, 78230 Le Pecq, France (E-mail : \\ auguste.bruchet@suez-env.com) \\ ** Cemagref, Groupement de Lyon, UR QELY, F-69336 LYON Cedex 09, France \\ *** LPTC - UMR 5472 CNRS - Université Bordeaux 1, 351 crs de la Libération, 33405 Talence, \\ France
}

\begin{abstract}
The fate of various emerging contaminants as well as priority pollutants from the European Union Water Framework directive was examined along a complex combination of natural and engineered processes used to produce drinking water downstream of a major metropolitan area. The sampling points examined comprised Seine river water downstream of the Paris area, water from a primary well after bank filtration, water from a secondary well influenced by an artificial recharge process and water from the mixture of secondary wells after drinking water treatment. More than 80 organic contaminants including drugs, polycyclic aromatic hydrocarbons, pesticides, oestrogenic hormones, PBDEs, chlorophenols, nonylphenols, drugs, were monitored during five campaigns. River bank filtration and to a lesser extent artificial recharge clearly decreased the variety of contaminants, in particular a variety of drugs detected in the river. On the other hand riverbank filtration was found to increase nonylphenols by anaerobic degradation of nonylphenolpolyethoxylate precursors. Traces of aspirin, nonylphenols and stimulants were occasionally detected in the finished drinking water above $0.1 \mu \mathrm{g} / 1$.
\end{abstract}

Keywords Artificial recharge; drinking water; drugs; emerging substances; nonylphenols; priority substances; riverbank filtration.

\section{INTRODUCTION}

Since the discovery of substances with endocrine disrupting properties (EDCs) and pharmaceutical substances in natural waters during the 1990s, a lot of research has been devoted to emerging substances. Emerging substances can be defined as non regulated compounds that represent a threat to human health or the aquatic environment. In addition to drugs and EDCs, emerging substances comprise a variety of man-made or natural substances such as fragrances (Ternes and Joss, 2006), benzotriazoles (Jover et al, 2009), UV filters (Zenker et al, 2008), organophosphate flame retardants (Andresen and Bester, 2006), perfluorinated chemicals (Becker et al, 2008)...In addition to emerging substances, the European Union (EU) has set environmental quality standards (EQS) for 33 priority substances in inland waters in order to restore their good chemical and ecological status (Official Journal, 2008). Urban wastewaters represent one of the major routes of introduction of emerging substances into natural waters. As an illustration, Semard et al have detected more than 1000 different compounds in a non treated urban wastewater (Semard et al, 2009). The benefits of wastewater treatment for the removal of hormones and nonylphenols have been demonstrated (Janex-Habibi et al, 2009). However, as the world population is increasing and aging and furthermore tends to concentrate in denser urban areas, conventional waste water treatment does not represent an absolute barrier for emerging contaminants and their levels in natural waters located downstream of metropolitan areas is likely to increase. Therefore production of safe drinking water requires a combination of physical (clarification, membrane filtration), chemisorption (activated carbon filtration) and oxidation (ozonation or advanced oxidation)-disinfection steps. Despite the efficiency of such processes, health 
authorities are often reluctant to allow direct abstraction of river water downstream of major cities for the production of drinking water. One such example is the Seine river downstream of Paris that can only be used for drinking water production after an additional artificial recharge process (Bruchet et al, 1991) or a combination of riverbank filtration-artificial recharge process. The objective of this paper is to illustrate the benefits of riverbank filtration coupled with an artificial recharge process and subsequent treatment at a drinking water plant, for the attenuation of various priority and emerging substances.

\section{METHODS}

\section{Study site}

The aquifer studied (Figure 1) is located along the Seine river, downstream of Paris and its urban wastewater plants. In particular, it is located downstream of a wastewater plant that treats the effluents from 6.5 million people at a rate of 2 million $\mathrm{m}^{3} /$ day.

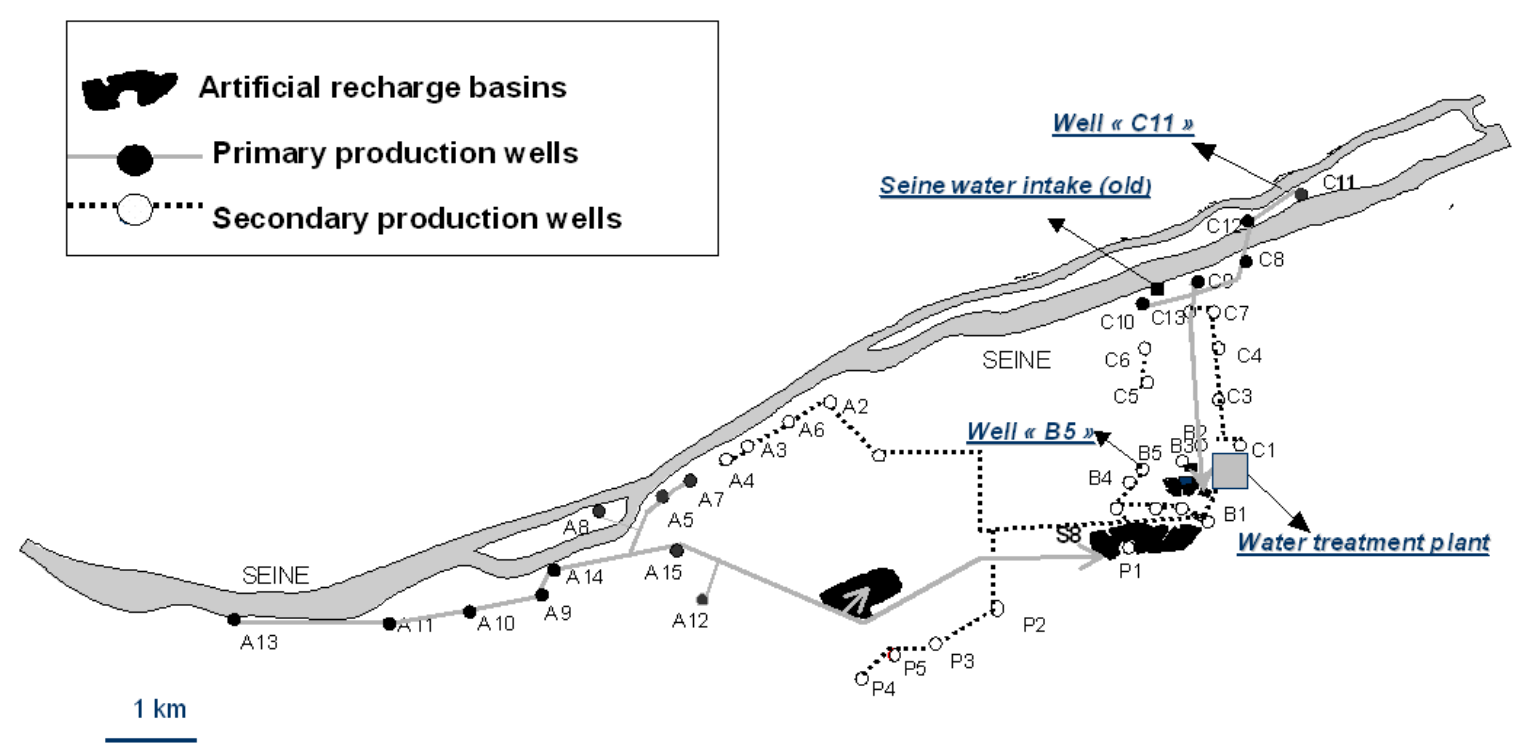

Figure 1 Description of study site

This aquifer covers an area of $40 \mathrm{~km}^{2}$ and comprises 36 primary and secondary wells. Primary wells are located mostly along the river and are naturally re-supplied under anoxic conditions through riverbank filtration. The mixture of primary wells is pumped and re-infiltrated through a sand-gravel artificial basin in order to recharge secondary production wells. This artificial recharge takes place under slightly aerobic conditions. This process that comprises active biological interfaces in anoxic-aerobic conditions allowed to replace drinking water treatment processes including settling, nitrification, iron and manganese removal and hence allowed a reduction in sludge production. Water from the mixture of secondary wells is further treated in a drinking water plant that comprises settling with addition of powdered activated carbon (PAC), sand filtration, ozonation and final disinfection with chlorine. The plant production is equal to $144,000 \mathrm{~m}^{3} /$ day. The following points were sampled (grab samples) on 5 occasions during September and October $2008: 1$ ) the Seine raw water, 2) primary production well 1 (one of the $C$ wells in figure 1) which is located on a small island on the Seine river and hence directly influenced by the river after bank filtration, 3) secondary well 2 (one of the B wells in figure 1) which is influenced by the main artificial recharge basin. However, due to the direction of underground flows, this well is also influenced by other areas of the aquifer and 4) the treated water at the outlet of the plant. 


\section{Analytical methods.}

A wide array of analytical methods was used to cover most priority pollutants and emerging contaminants. Volatile organic compounds (VOC's) were determined by Purge and Trap gas chromatography-mass spectrometry (GC/MS). 25 semi-volatile priority pollutants including the 6 indicator polycyclic aromatic hydrocarbons (PaHs) and naphthalene, anthracene, plus various pesticides or degradates (1,2,4-trichlorobenzene, pentachlorobenzene, trifluralin, HCB, chlorpyryphos-methyl and ethyl, alachlor, aldrin, isodrin, dieldrin, endrin, 4,4'-DDT, chlorfenvinphos), hexachlorobutadiene and diethylhexylphtalate (DEHP) were determined together by gas GC/MS after liquid-liquid-extraction followed by Florisil purification. 4 herbicides (atrazine, diuron, isoproturon, simazine) and two antibiotics (sulfamethoxazole and roxythromycin) were determined together by solid phase extraction (SPE) on OASIS HLB followed by liquid chromatography-mass spectrometry (LC/MS/MS) in electrospray positive ion mode $\left(\mathrm{ESI}^{+}\right)$. Pentachlorophenol and 8 other halogenated phenols were determined by solid phase microextraction (SPME) on DVB/CAR/PDMS-GC/MS, glyphosate and AMPA were determined by FMOC derivatization-HPLC-fluorescence. Chloroalkanes and polybrominated diphenylethers (11 congeners from penta to deca-BDE) were determined by GC/ECD and GC/MS after stir-bar-sorptive-extraction (SBSE). 5 estrogenic hormones $(\alpha-$ and $\beta$-estradiol, ethinylestradiol, estriol and estrone were measured by SPE (Oasis-HLB)LC/MS/MS in ESI mode after enzymatic deconjugation (Miège et al, 2009). 4-nonylphenol (4-NP), 4-t-octylphenol (4-OP), 4-NP1EO, 4-NP2EO and 4-NP1EC were determined by SPE (Bond Elut $\left.{ }^{\circledR} \mathrm{C} 18\right)-\mathrm{UPLC} / \mathrm{MS} / \mathrm{MS}$ in $\mathrm{ESI}^{-}$and $\mathrm{ESI}^{+}$mode. Ten $\beta$-blockers were measured by SPE (Oasis MCX)-LC-MS/MS in ESI ${ }^{+}$mode. Non steroidal analgesics, antidepressants, tranquillizers, lipid regulators, vasodilatators and stimulants were determined by SPE (OasisMCX)-LC-MS/MS in ESI ${ }^{-}$and ESI mode. Details concerning these methods and their performances can be obtained from the authors.

\section{RESULTS AND DISCUSSION}

During the five sampling campaigns, total organic carbon (TOC) in the Seine river varied from 2.3 to $2.9 \mathrm{mg} / \mathrm{l}$, with one exception of unknown origin at $12.6 \mathrm{mg} / \mathrm{l}$. This is significantly lower than in the past when the TOC downstream of Paris often ranged from 6 to $8 \mathrm{mg} / \mathrm{l}$. This illustrates the quality improvement of surface waters downstream of a major metropolitan area after the extension of existing, or the start-up of new wastewater plants. The TOC in the 1 and 2 wells varied from 0.9 to $1.1 \mathrm{mg} / \mathrm{l}$, clearly illustrating the benefit of riverbank filtration and artificial recharge for natural organic matter removal. At the outlet of the drinking water plant, the TOC was further reduced to $0.7-0.8 \mathrm{mg} / \mathrm{l}$.

\section{Compounds undetected in the Seine river}

Although the sampling point on the Seine river is located downstream of a metropolitan area with 11 million people, most EU priority compounds were never detected : the $\mathrm{C}_{10}-\mathrm{C}_{13}$ chloroalkanes $(<0.5 \mu \mathrm{g} / \mathrm{l})$, the $11 \mathrm{PBDE}$ congeners $(<10 \mathrm{ng} / \mathrm{l})$, pentachlorophenol and 8 other mono, di, tri and tetrachlorinated or brominated phenols, some of which have been reported in untreated and treated urban wastewaters (Bruchet et al, 2008), implying that they were below their limits of quantification (LOQ) of 25 or $50 \mathrm{ng} / \mathrm{l}$. 23 out of the 29 semi volatile priority pollutants investigated by GC/MS were never detected in the Seine river or aquifer water (most LOQs were equal to $10 \mathrm{ng} / \mathrm{l}$ ). These include the PAH's (with the exception of fluoranthene), most pesticides or degradates (1,2,4-trichlorobenzene, pentachlorobenzene, trifluralin, HCB, chlorpyryphos-methyl and ethyl, alachlor, aldrin, isodrin, dieldrin, endrin, 4,4'-DDT, chlorfenvinphos) and hexachlorobutadiene. Trace levels of VOCs including dichloromethane, chloroform, trichloroethylene, tetrachloroethylene and cis-1,2- 
dichloroethylene were detected in the Seine river, at levels ranging from 0.1 to $0.4 \mu \mathrm{g} / \mathrm{l}$, far below their environmental quality standards. The wells 1 and 2 contained a higher level of cis-1,2-dichloroethylene $(0.5-1 \mu \mathrm{g} / \mathrm{l})$ and especially trichloroethylene (5 to $8 \mu \mathrm{g} / \mathrm{l}$ ), reminiscent of a past contamination with industrial solvents. The levels of chlorinated solvents remained below $1 \mu \mathrm{g} / \mathrm{l}$ in the finished drinking water.

\section{Semi-volatile priority substances}

Fluoranthene was measured at a level of 10-15 ng/l in the Seine river water (Table 1), much below its EQS for inland waters (100 ng/l). As expected from its high octanol/water partition coefficient (Kow>5) this compound is removed during riverbank filtration, very likely by adsorption. Although blank levels for diethylhexylphtalate were quite low $(<15 \mathrm{ng} / \mathrm{l})$, this compound was present throughout the whole system without showing any clear trend. This may be due to a combination of soil adsorption (Kow>5) and desorption by plastic materials in the wells or the treatment plant. The 4 herbicides determined by HPLC/MS/MS (atrazine, simazine, diuron isoproturon) are found in the river at levels ranging from 1 to $50 \mathrm{ng} / \mathrm{l}$, much lower than levels observed a decade ago (Jaskulké et al, 1999). It is interesting to note the persistence of atrazine and simazine which were withdrawn from the market at the end of 2004. Their level is unchanged after bank filtration (well 1) while it tends to be higher in the well influenced by the artificial recharge and other underground water flows (well 2). This illustrates their long term persistence in the aquifer that was contaminated by higher levels in the past. Only atrazine is detected in the drinking water at a level below $10 \mathrm{ng} / \mathrm{l}, 10$ times below the maximum contaminant level (MCL) for pesticides $(100 \mathrm{ng} / \mathrm{l})$. The only pesticide or degradate found at a level exceeding $0.1 \mu \mathrm{g} / \mathrm{l}$ in the Seine river is glyphosate (on one occasion) and its degradate AMPA (systematically in the range 0.25-0.65 $\mu \mathrm{g} / \mathrm{l}$ ). These two compounds are totally removed by bank filtration, in accordance with previous observations (Reemtsma and Jekel, 2002) and do not reappear in the aquifer.

\section{Hormones and alkylphenols}

Total (deconjugated) hormones were measured during two campaigns in October 2008. Only $17-\beta$-estradiol and estrone were detected in the Seine river at a level of $0.4-1.0 \mathrm{ng} / \mathrm{l}$ and 1.4$2.2 \mathrm{ng} / \mathrm{l}$, respectively. Bank filtration reduces estrone below its quantification limit $(<0.2$ $\mathrm{ng} / \mathrm{l})$. Unexpectedly, a trace of $17-\beta$-estradiol is detected in wells 1 and $2(0.6-0.7 \mathrm{ng} / \mathrm{l})$ and even more unexpectedly, in the finished drinking water. This result was obtained by LC/MS/MS in the multiple reaction monitoring (MRM mode) and was not further confirmed by full scan MS/MS. This result should hence be considered with extreme caution, as the processes in use at the plant (PAC and especially ozone) are known to be very efficient at removing hormones. Traces of 4-nonylphenols $(0.07$ to $0.2 \mu \mathrm{g} / \mathrm{l})$ and 4-t-octylphenol (from $<$ LOQ to $0.05 \mu \mathrm{g} / \mathrm{l})$, as well as their ethoxylates NP1EO and NP2EO $(0,01-0,13 \mu \mathrm{g} / \mathrm{l}$ and their acidic by-products (4-NP1EC) were found in the Seine river. 4-NP and 4-t-OP significatly increased by a factor of 10 and 17, during bank filtration. This is most likely due to a transformation of alkylphenol polyethoxylates (not measured) which are normally present at higher levels, into the lower molecular weight 4-NP and 4-t-OP. This transformation is known to take place under anaerobic conditions such as during anaerobic digestion of sewage sludge (Janex-Habibi et al, 2009). By contrast, NP1EO and NP2EO show a decrease during bank filtration. The different forms of alkylphenols are significantly reduced during artificial recharge as shown by their lower level in well 2 , and are further reduced by the drinking water plant. The detection of low levels of 4-NP in the drinking water $(0.04-0.18 \mu \mathrm{g} / \mathrm{l})$, although much lower than levels found e.g. in Canada (Ministère de l'environnement du Québec, 2003) will deserve further investigation. 
Table 1. Fate of priority and emerging contaminants during bank filtration (C11), artificial recharge (B5) and drinking water treatment

\begin{tabular}{|c|c|c|c|c|c|}
\hline Parameter & Unit & $\begin{array}{c}\text { Seine river } \\
n=5\end{array}$ & $\begin{array}{c}\text { C11 well } \\
n=5\end{array}$ & $\begin{array}{c}\text { B5 well } \\
n=5\end{array}$ & $\begin{array}{c}\text { Drinking water } \\
n=5\end{array}$ \\
\hline \multicolumn{6}{|l|}{ Semi-volatiles compounds } \\
\hline Fluoranthene & $\mathrm{ng} / \mathrm{l}$ & $9-14$ & $<10$ & $<10$ & $<10$ \\
\hline DEHP & $\mathrm{ng} / \mathrm{l}$ & $191-675$ & $367-509$ & $320-2013$ & $243-521$ \\
\hline Atrazine & $\mathrm{ng} / \mathrm{l}$ & $17-23$ & $19-23$ & $34-50$ & $3-9$ \\
\hline Diuron & $\mathrm{ng} / \mathrm{l}$ & $32-40$ & $58-73$ & $26-52$ & $<1$ \\
\hline Isoproturon & $\mathrm{ng} / \mathrm{l}$ & $<1-3$ & $24-35$ & $15-31$ & $<1$ \\
\hline Simazine & $\mathrm{ng} / \mathrm{l}$ & $3-9$ & $6-10$ & $7-15$ & $<1$ \\
\hline Glyphosate & $\mu g / l$ & $<0.1-0.12$ & $<0.1$ & $<0.1$ & $<0.1$ \\
\hline AMPA & $\mu \mathrm{g} / \mathrm{l}$ & $0.25-0.65$ & $<0.1$ & $<0.1$ & $<0.1$ \\
\hline \multicolumn{6}{|l|}{ Alkylphenols } \\
\hline 4-NP (Nonylphenols) & $\mu g / l$ & $0.06-0.21$ & $0.45-1.71$ & $0.06-0.29$ & $0.05-0.18$ \\
\hline 4-t-OP (Octylphenols) & $\mu \mathrm{g} / \mathrm{l}$ & $<0.01-0.05$ & $0.05-0.57$ & $<0.01-0.02$ & $<0.01-0.03$ \\
\hline 4-NP1EO & $\mu \mathrm{g} / \mathrm{l}$ & $0.02-0.11$ & $0.04-0.19$ & $0.02-0.04$ & $0.002-0.04$ \\
\hline 4-NP2EO & $\mu \mathrm{g} / \mathrm{l}$ & $0.01-0.13$ & $0.03-011$ & $0.01-0.04$ & $0.01-0.08$ \\
\hline 4-NP1EC & $\mu \mathrm{g} / \mathrm{l}$ & 0.08 & 0.19 & $0.03-0.01$ & $<0.001-0.003$ \\
\hline \multicolumn{6}{|l|}{ Beta-blockers } \\
\hline Atenolol & $\mathrm{ng} / \mathrm{l}$ & $99.5-155.2$ & $<$ LoQ-6.6 & $0.7-2.5$ & $<$ LoQ-1.6 \\
\hline Sotalol & $\mathrm{ng} / \mathrm{l}$ & $65.9-117.1$ & 3.3-12.1 & $<$ LoQ-3.8 & $<$ LoQ-0.6 \\
\hline Nadolol & $\mathrm{ng} / \mathrm{l}$ & $1-4$ & $<$ LoQ & $<L O Q$ & $<L O Q$ \\
\hline Timolol & $\mathrm{ng} / \mathrm{l}$ & $<$ LoQ-0 .5 & $<$ LoQ & $<$ LoQ & $<$ LoQ \\
\hline Acetobutolol & $\mathrm{ng} / \mathrm{l}$ & $32.9-75.6$ & $0.6-1.6$ & $3.3-6.2$ & $<$ LoQ-1.2 \\
\hline Metoprolol & $\mathrm{ng} / \mathrm{l}$ & $8.5-13.5$ & $<$ LoQ-0.9 & $<$ LoQ-0.4 & $<$ LoQ-0.4 \\
\hline Oxprenolol & $\mathrm{ng} / \mathrm{l}$ & $<$ LoQ-1.7 & $<L o Q$ & $<L o Q$ & $<L o Q$ \\
\hline Propanolol & $\mathrm{ng} / \mathrm{l}$ & $8.8-30.6$ & $<$ LoQ & $<$ LoQ-0.6 & $<$ LoQ-0.5 \\
\hline Betaxolol & $\mathrm{ng} / \mathrm{l}$ & $<$ LoQ-1.7 & $<$ LoQ & $<$ LoQ-0.5 & $<$ LoQ \\
\hline Bisoprolol & $\mathrm{ng} / \mathrm{l}$ & $7.5-12.5$ & $<$ LoQ-0.3 & $<$ LoQ-0.3 & $<$ LoQ-0.5 \\
\hline
\end{tabular}

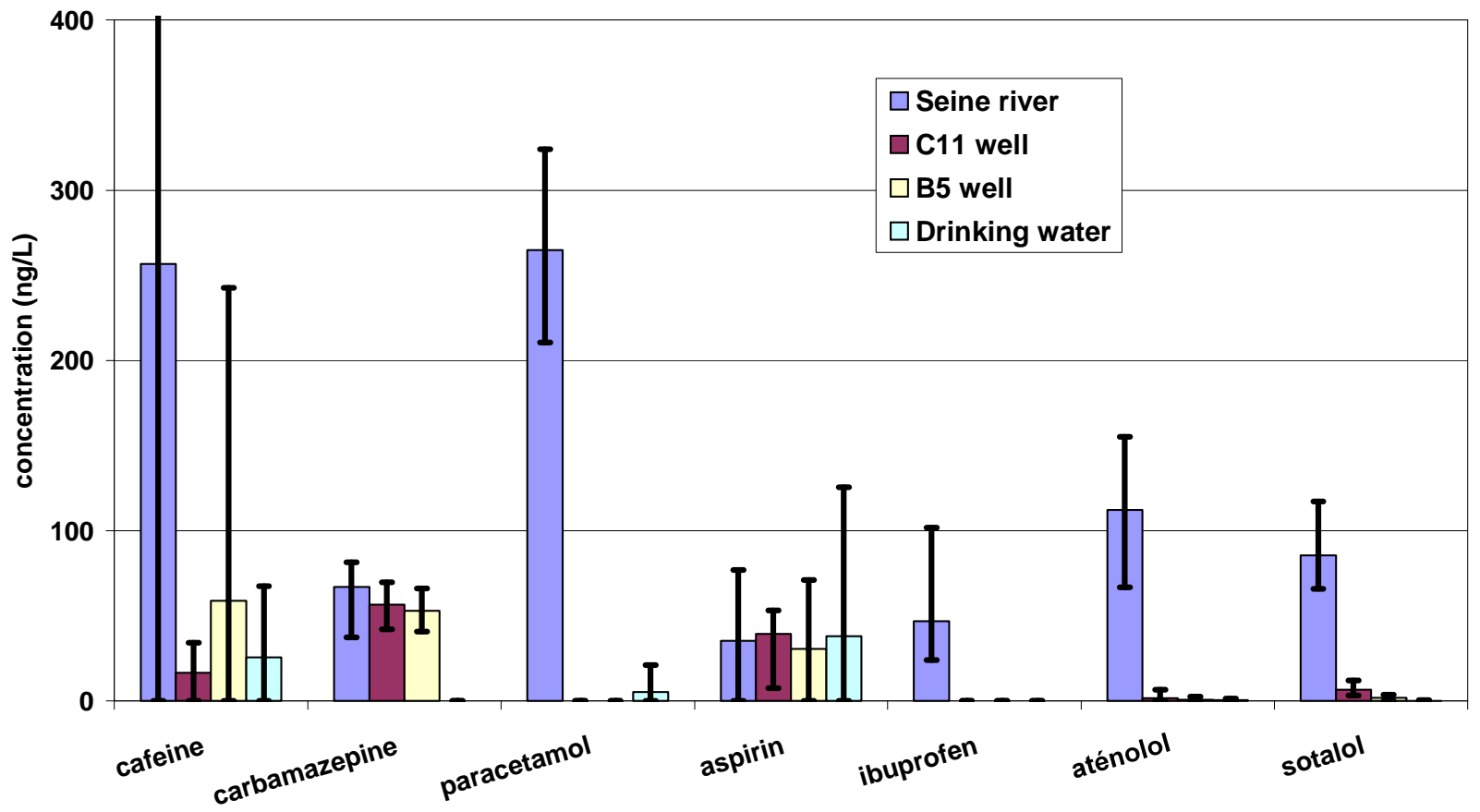

Figure 1. Evolution of drugs and stimulants 
Table 2. Fate of drugs and stimulants during bank filtration, artificial recharge and drinking water treatment.

\begin{tabular}{|c|c|c|c|c|c|c|c|c|c|c|c|c|c|c|c|c|c|c|c|c|c|}
\hline \multirow{3}{*}{ Parameter } & \multirow{3}{*}{ Unit } & \multicolumn{5}{|c|}{ SEINE River } & \multicolumn{5}{|c|}{ C11 Well } & \multicolumn{5}{|c|}{ B5 Well } & \multicolumn{5}{|c|}{ Chlorinated Water } \\
\hline & & \multicolumn{20}{|c|}{2008} \\
\hline & & 9-sept & 16-sept & 23-sept & 13-oct & 20 -oct & 9-sept & 16-sept & 23-sept & 13-oct & 20 -oct & 9-sept & 16-sept & 23-sept & 13-oct & 20 -oct & 9-sept & 16-sept & 23-sept & 13-oct & 20 -oct \\
\hline \multicolumn{22}{|l|}{ Other Drugs } \\
\hline cafeine & $\mathrm{ng} / \mathrm{l}$ & 315,0 & $\angle \mathrm{LoQ}$ & 103,5 & 530,3 & 335,1 & $\angle \mathrm{LOQ}$ & $<\mathrm{LOQ}$ & \multirow{23}{*}{ ND } & 32,0 & 34,3 & 11,7 & 15,2 & $<\mathrm{LOQ}$ & 242,7 & 24,4 & 67,4 & $<\mathrm{LOQ}$ & $<\mathrm{LoQ}$ & 34,7 & \multirow{21}{*}{ ND } \\
\hline carbamazepine & $\mathrm{ng} / \mathrm{l}$ & 81,5 & 37,3 & 72,0 & 68,9 & 75,6 & 69,9 & 42,1 & & 53,8 & 60,6 & 57,1 & 40,8 & 66,1 & 49,2 & 51,5 & $<\mathrm{LOQ}$ & $\angle \mathrm{LOQ}$ & $<\mathrm{LOQ}$ & $\angle \mathrm{LOQ}$ & \\
\hline diazepam & $\mathrm{ng} / \mathrm{l}$ & 1,4 & $<\mathrm{LOQ}$ & $<\mathrm{LOQ}$ & $<L O Q$ & $<\mathrm{LOQ}$ & 1,9 & 2,7 & & $\angle \mathrm{LOQ}$ & 1,5 & 0,0 & $<\mathrm{LOQ}$ & $\angle \mathrm{LOQ}$ & $\angle \mathrm{LoQ}$ & 0,0 & $<\mathrm{LOQ}$ & $<\mathrm{LOQ}$ & $<\mathrm{LOQ}$ & $<\mathrm{LOQ}$ & \\
\hline nordiazepam & $\mathrm{ng} / \mathrm{l}$ & 3,9 & 3,4 & 1,8 & 3,8 & 1,5 & 1,0 & $<\mathrm{LOQ}$ & & 0,0 & $\angle \mathrm{LOQ}$ & $<\mathrm{LoQ}$ & $<\mathrm{LOQ}$ & $\angle \mathrm{LoQ}$ & 1,2 & $\angle \mathrm{LOQ}$ & $<\mathrm{LOQ}$ & $\angle \mathrm{LOQ}$ & $\angle \mathrm{LOQ}$ & 0,7 & \\
\hline Amitriptyline & $\mathrm{ng} / \mathrm{l}$ & 3,6 & 4,1 & 6,3 & 3,4 & 3,2 & $<\mathrm{LOQ}$ & 0,9 & & $\angle \mathrm{LOQ}$ & $\angle \mathrm{LOQ}$ & $<\mathrm{LOQ}$ & $<\mathrm{LOQ}$ & $\angle \mathrm{LOQ}$ & 1,2 & $<\mathrm{LOQ}$ & $<\mathrm{LOQ}$ & $<\mathrm{LOQ}$ & $<\mathrm{LoQ}$ & $\angle \mathrm{LOQ}$ & \\
\hline doxepine & $\mathrm{ng} / \mathrm{l}$ & $<\mathrm{LoQ}$ & $\angle \mathrm{LoQ}$ & $\angle \mathrm{LOO}$ & $\angle \mathrm{LOQ}$ & $\angle \mathrm{LoQ}$ & $\angle \mathrm{LOQ}$ & $\angle \mathrm{LOQ}$ & & $\angle \mathrm{LOQ}$ & $<\mathrm{LOQ}$ & $<\mathrm{LoQ}$ & $\angle \mathrm{LOQ}$ & $<\mathrm{LOQ}$ & $<\mathrm{LOQ}$ & $\angle \mathrm{LOQ}$ & $\angle \mathrm{LOQ}$ & $\angle \mathrm{LOQ}$ & $<\mathrm{LoQ}$ & $\angle L O Q$ & \\
\hline imipramine & $\mathrm{ng} / \mathrm{l}$ & 0,5 & $\angle L O Q$ & $\angle \mathrm{LoO}$ & $\angle \mathrm{LOQ}$ & $\angle \mathrm{LoQ}$ & $<\mathrm{LoO}$ & $<\mathrm{LoQ}$ & & $\angle \mathrm{LoQ}$ & $\angle \mathrm{LoQ}$ & $<\mathrm{LoQ}$ & $<\mathrm{LoQ}$ & $<\mathrm{LOQ}$ & $<\mathrm{LoQ}$ & $\angle \mathrm{LoQ}$ & $<\mathrm{LoQ}$ & $<L O Q$ & $<\mathrm{LoQ}$ & $\angle L O Q$ & \\
\hline ibuprofene & $\mathrm{ng} / \mathrm{l}$ & 31,8 & 101,9 & 26,4 & 49,9 & 24,2 & $\angle \mathrm{LoQ}$ & $\angle \mathrm{LOQ}$ & & $<\mathrm{LoQ}$ & $\angle \mathrm{LoQ}$ & $<\mathrm{LoQ}$ & $<\mathrm{LoQ}$ & $\angle \mathrm{LoQ}$ & $<\mathrm{LoQ}$ & $\angle \mathrm{LoQ}$ & $\angle \mathrm{LOQ}$ & $\angle L O Q$ & $<\mathrm{LoQ}$ & $<L_{0 Q}$ & \\
\hline paracetamol & $\mathrm{ng} / \mathrm{l}$ & 251,1 & 210,5 & 292,3 & 324,1 & 246,6 & $\angle \mathrm{LOQ}$ & $\angle \mathrm{LOQ}$ & & $\angle \mathrm{LOQ}$ & $\angle \mathrm{LOQ}$ & $<\mathrm{LoQ}$ & $<\mathrm{LOQ}$ & $\angle \mathrm{LOQ}$ & $\angle \mathrm{LOQ}$ & $\angle \mathrm{LOQ}$ & $\angle \mathrm{LOQ}$ & $\angle L O Q$ & 21,1 & $\angle L_{0 Q}$ & \\
\hline ketoprofene & $\mathrm{ng} / \mathrm{l}$ & 16,1 & 12,7 & 0,0 & 0,0 & 0,0 & 10,6 & 7,3 & & 20,9 & 5,2 & 6,0 & 0,9 & 5,2 & 25,5 & $\angle \mathrm{LOQ}$ & 6,4 & 1,2 & $<\mathrm{LoQ}$ & 0,0 & \\
\hline naproxene & $\mathrm{ng} / \mathrm{l}$ & 39,8 & 24,4 & 27,6 & 40,4 & 34,7 & $\angle \mathrm{LOQ}$ & $\angle \mathrm{LOQ}$ & & $\angle \mathrm{LoQ}$ & $\angle \mathrm{LoQ}$ & $<\mathrm{LoQ}$ & $<\mathrm{LOQ}$ & $\angle \mathrm{LOQ}$ & 1,0 & $\angle \mathrm{LOQ}$ & $\angle \mathrm{LOQ}$ & $\angle \mathrm{LoQ}$ & $<\mathrm{LoQ}$ & $<L_{0 Q}$ & \\
\hline aspirine & $\mathrm{ng} / \mathrm{l}$ & 22,9 & $\angle L o Q$ & 8,6 & 77,1 & 68,1 & 53,2 & 7,6 & & 50,7 & 46,2 & 71,1 & 11,9 & 6,5 & 63,2 & $\angle \mathrm{LOQ}$ & $<\mathrm{LoQ}$ & 17,0 & 9,6 & 125,6 & \\
\hline diclofenac & $\mathrm{ng} / \mathrm{l}$ & 60,5 & 52,2 & 74,5 & 76,7 & 75,0 & 11,2 & 11,1 & & 9,3 & 11,5 & 3,2 & 3,9 & 0,9 & 2,9 & 2,3 & $\angle \mathrm{LOQ}$ & 1,5 & $<\mathrm{LoQ}$ & 0,0 & \\
\hline gemfibrozil & $\mathrm{ng} / \mathrm{l}$ & 10,3 & 7,9 & 7,8 & 12,4 & 8,8 & 0,9 & 1.4 & & 0,8 & $\angle \mathrm{LoQ}$ & $<\mathrm{LoQ}$ & 0,0 & $\angle \mathrm{LOQ}$ & $\angle \mathrm{LoO}$ & $\angle \mathrm{LoQ}$ & $\angle \mathrm{LoQ}$ & 0,6 & $<\mathrm{LoQ}$ & $\angle \mathrm{LOQ}$ & \\
\hline clenbuterol & $\mathrm{ng} / \mathrm{l}$ & $<\mathrm{LoQ}$ & 2,3 & 0,9 & $\angle \mathrm{LoQ}$ & $\angle \mathrm{LoQ}$ & $\angle \mathrm{LoQ}$ & 1,6 & & $\angle L O Q$ & $\angle \mathrm{LoQ}$ & 0,7 & $<\mathrm{LoQ}$ & 0,0 & $\angle \mathrm{LoQ}$ & $\angle \mathrm{LOQ}$ & $\angle \mathrm{LoQ}$ & 1,7 & $<\mathrm{LoQ}$ & $\angle \mathrm{LoQ}$ & \\
\hline salbutamol & $\mathrm{ng} / \mathrm{l}$ & 1,6 & $\angle L o Q$ & 1,2 & 0,9 & 1,7 & $<\mathrm{LoQ}$ & $\angle \mathrm{LOQ}$ & & $\angle \mathrm{LOQ}$ & $\angle \mathrm{LOQ}$ & $<\mathrm{LoQ}$ & $<\mathrm{LOQ}$ & $<\mathrm{LOQ}$ & $<\mathrm{LoQ}$ & 2,4 & 0,5 & $\angle \mathrm{LoQ}$ & $<\mathrm{LoQ}$ & $<L_{0 Q}$ & \\
\hline terbutaline & $\mathrm{ng} / \mathrm{l}$ & 1,8 & $\angle \mathrm{LoQ}$ & 2,0 & $\angle \mathrm{LOQ}$ & 1,8 & $\angle \mathrm{LoQ}$ & $\angle \mathrm{LoQ}$ & & $\angle \mathrm{LoQ}$ & $\angle \mathrm{LoQ}$ & $<\mathrm{LoQ}$ & $<\mathrm{LoQ}$ & 1,0 & $\angle \mathrm{LoQ}$ & $\angle \mathrm{LOQ}$ & $\angle \mathrm{LoQ}$ & $\angle \mathrm{LOQ}$ & $<\mathrm{LoQ}$ & $\angle \mathrm{LOQ}$ & \\
\hline Théophylline & $\mathrm{ng} / \mathrm{l}$ & 73,2 & $\angle \mathrm{LoQ}$ & 70,7 & 152,3 & 101,3 & $<\mathrm{LoQ}$ & $<\mathrm{LoQ}$ & & 7,2 & $<L 0 Q$ & $<\mathrm{LoQ}$ & 332,5 & $<\mathrm{LOQ}$ & 2,8 & $<\mathrm{LOQ}$ & $\angle \mathrm{LoQ}$ & $<L_{0 Q}$ & 10,2 & 1,1 & \\
\hline Alprazolam & $\mathrm{ng} / \mathrm{l}$ & $<\mathrm{LoQ}$ & 0,0 & $\angle \mathrm{LOO}$ & $\angle \mathrm{LOQ}$ & $\angle \mathrm{LOQ}$ & $\angle \mathrm{LOO}$ & $\angle \mathrm{LoQ}$ & & $\angle \mathrm{LoQ}$ & $\angle \mathrm{LoQ}$ & $<\mathrm{LoQ}$ & $<\mathrm{LOQ}$ & $\angle \mathrm{LoQ}$ & $<\mathrm{LoQ}$ & $\angle \mathrm{LOQ}$ & $\angle \mathrm{LoQ}$ & $\angle \mathrm{LOQ}$ & $<\mathrm{LoQ}$ & $\angle \mathrm{LOQ}$ & \\
\hline Bromazépam & $\mathrm{ng} / \mathrm{l}$ & $<\mathrm{LoQ}$ & $\angle L_{0} Q$ & $\angle \mathrm{LoQ}$ & 0,0 & $\angle \mathrm{LOQ}$ & $\angle \mathrm{LoQ}$ & $<\mathrm{LoQ}$ & & 5,6 & $\angle \mathrm{LoQ}$ & $<\mathrm{LoQ}$ & $<\mathrm{LoQ}$ & $<\mathrm{LOQ}$ & $<\mathrm{LoQ}$ & $\angle \mathrm{LoQ}$ & $\angle \mathrm{LoQ}$ & $\angle L O Q$ & $<\mathrm{LoQ}$ & $\angle \mathrm{LOQ}$ & \\
\hline Fluoxétine & $\mathrm{ng} / \mathrm{l}$ & 1,5 & $\angle \mathrm{LoQ}$ & 1,4 & 1,2 & 0,9 & $\angle \mathrm{LoQ}$ & $\angle \mathrm{LOQ}$ & & $\angle \mathrm{LOQ}$ & $\angle \mathrm{LOQ}$ & $<\mathrm{LoQ}$ & 0,7 & $\angle L O Q$ & $<L o Q$ & $\angle \mathrm{LOQ}$ & $\angle \mathrm{LoQ}$ & $\angle L O Q$ & $<\mathrm{LoQ}$ & $\angle L O Q$ & \\
\hline Sulphamethoxazole & $\mathrm{ng} / \mathrm{l}$ & ND & 24,0 & \multicolumn{2}{|c|}{ ND } & 116,0 & 6,0 & 6,0 & & 6,0 & 8,0 & $<\mathrm{LoQ}$ & $<\mathrm{LoQ}$ & ND & $<\mathrm{LoQ}$ & $\angle \mathrm{LOQ}$ & $<\mathrm{LOQ}$ & $<\mathrm{LOQ}$ & ND & $\angle \mathrm{LOQ}$ & $\angle \mathrm{LOQ}$ \\
\hline Roxythromicine & $\mathrm{ng} / \mathrm{l}$ & $\angle \mathrm{LoQ}$ & $\angle \mathrm{LoQ}$ & $\angle \mathrm{LoQ}$ & 16,0 & 16,0 & $\angle \mathrm{LOQ}$ & $\angle \mathrm{LOQ}$ & & $\angle \mathrm{LOQ}$ & $\angle \mathrm{LOQ}$ & $\angle \mathrm{LoQ}$ & $\angle \mathrm{LoO}$ & $\angle \mathrm{LOQ}$ & $<\mathrm{LoQ}$ & $\angle \mathrm{LOQ}$ & $\angle \mathrm{LOQ}$ & $\angle \mathrm{LOQ}$ & $\leq \mathrm{LOQ}$ & $\angle \mathrm{LOQ}$ & $\angle \mathrm{LOQ}$ \\
\hline & & & & & & & & & & & & & & & & & & & & & \\
\hline ND - No Determined & & & & & & & & & & & & & & & & & & & & & \\
\hline
\end{tabular}




\section{Drugs and stimulants}

Drugs from various therapeutic classes were found in the Seine river (Table 1 and Table 2). Two beta-blockers (sotalol and atenolol) exceeded $100 \mathrm{ng} / \mathrm{l}$ while acebutolol reached $75 \mathrm{ng} / \mathrm{l}$. These compounds were drastically reduced by bank filtration and did not exceed $6 \mathrm{ng} / \mathrm{l}$ in the aquifer and were decreased below $2 \mathrm{ng} / \mathrm{l}$ at the outlet of the drinking water plant. A complex set of other drugs was also found in the river. The highest level was recorded for paracetamol with was consistently found between 250 and $330 \mathrm{ng} / \mathrm{l}$. This seems to imply that downstream of major metropolitan areas, drugs are now present at levels equivalent to, or higher than, levels of pesticides. Stimulants such as caffeine (up to $530 \mathrm{ng} / \mathrm{l}$ ) and theophyllin (up to 100 $\mathrm{ng} / \mathrm{l}$ ) widely used in beverages are also outstanding. Carbamazepin, one of the most persistent drugs is found at a rather constant level of $37-75 \mathrm{ng} / \mathrm{l}$. It is of interest to note that a variety of antidepressants (imipramine, fluoxetine) and tranquillizers is also detected in the river water, albeit at low levels. Except for carbamazepin and aspirin, the benefit of bank filtration is clearly visible in Figure 1. Infiltration through the artificial recharge basin brings an additional benefit for a few compounds (diazepam, ketoprofen, diclofenac, sulphamethoxazole). The drinking water plant is quite efficient at removing the few drugs and stimulants detected in the aquifer, in particular carbamazepin and ketoprofen. Finally, only one drug (aspirin) and the two stimulants are found in excess of $10 \mathrm{ng} / \mathrm{l}$ at the plant outlet. The occasional presence of such compounds in tap water is not considered as a health risk.

\section{Conclusions}

The present study allowed to measure most priority substances from the EU Water Framework Directive and a wide variety of emerging substances in a surface water downstream of a major metropolitan area that treats the majority of its urban wastewaters (the Seine river downstream of Paris). The study site selected allowed to observe the fate of the substances detected, during their infiltration into an aquifer primarily re-supplied by natural bank filtration. The fate of the substances reaching the aquifer was monitored along a natural recharge process and at the outlet of a drinking water plant treating a mixture of boreholes from this aquifer. Major conclusions from the current study are the following:

-Priority substances are observed (chlorinated solvents, DEHP, fluoranthene, atrazine, simazine, diuron, , 4-nonyl and 4-t-octylphenol) in the Seine river water at levels below their environmental quality standards (EQS).

-Numerous emerging substances such as estrogenic hormones of human origin as well as various drugs belonging to most therapeutic classes (beta-blockers, antibiotics, analgesics, anti-inflammatory drugs, cholesterol reducers, antidepressants and tranquillizers) have been found in the Seine river. Estrogenic hormones are sometimes present at a low level (1-3 ng/l) still likely to induce disrupting effects on the aquatic fauna. Specific drugs are detected at levels between 0.1 and $0.4 \mu \mathrm{g} / \mathrm{l}$. With the exception of the glyphosate herbicide and its degradate AMPA, drugs are now found at a general level exceeding that from pesticides.

- Some compounds or groups of compounds have never been found in any sampling point : this was the case for 3 volatile organic compounds (VOCs), - benzene, 1,2-dichloroethane and carbon tetrachloride-, most of the semi-volatile compounds investigated - e.g. polycyclic aromatic hydrocarbones (PAHs) -, chloroalkanes, PBDE, chlorophenols and some pharmaceuticals.

-Natural river bank filtration is beneficial for the attenuation of select priority substances (fluoranthene) and a wide range of emerging substances. In particular, many drugs and stimulants are decreased during their infiltration into the aquifer. 
-By contrast, natural bank filtration which essentially takes place under anaerobic conditions, induces the transformation of polyethoxylated alkylphenols into 4-nonylphenol and 4nonylphenol-1-ethoxycarboxylate.

-No beneficial effect of river bank filtration could be demonstrated for chlorinated solvents and pesticides that are already present in the aquifer.

-In a system influenced by urban wastewaters downstream of a major metropolitan area, a drinking water produced by a complex combination of natural bank filtration, artificial recharge, clarification with powdered activated carbon addition, ozonation and chlorination, complies with the current legislation. It however occasionally reveals traces of emerging contaminants including nonylphenols and drugs/stimulants (especially aspirin) at a level exceeding $0.1 \mu \mathrm{g} / \mathrm{l}$. The presence of the 4-nonylphenol endocrine disruptor in drinking waters produced from influenced resources warrants further investigation. Also, the results from this study should be confirmed by additional campaigns covering other hydrological conditions such as summer low flow conditions.

Acknowledgements. This project was co-funded by the French National Research Agency (ANR), as part of the AMPERES project. The authors wish to thank P. Bados for analysis of hormones and S Schiavone for analysis of beta-blockers.

\section{References}

Andresen, J., Bester, K. (2006). Elimination of organophosphate ester flame retardants and plasticizers in drinking water purification. Water research, 40, 621-629.

Becker, A.M., Gerstmann, S., Frank, H. (2008). Perfluorooctane surfactants in waste waters, the major source of river pollution. Chemosphere 72, 115-121.

Bruchet, A., N'Guyen, K., Legrand, M.F., Mallevialle, J. (1991). Variations in Organic and Organoleptic Water Quality During Treatment of Artificially Recharged Groundwater. Journal AWWA, 83, 3, 63-70.

Bruchet, A., Prolongeau, C., Esperanza, M., Coquery, M. (2008). Where do the halogenated phenols in drinking water resources come from?. Water Science and Technology: Water Supply-WSTWS, 8.3.2008, 263-269.

Jaskulké, E., Patty, L., Bruchet, A.(1999). Evaluation of Pesticide Residues in Water. In Pesticide Chemistry and Bioscience. The Food-Environment Challenge. Edited by G.T. Brooks and T.R. Roberts.The Royal Society of Chemistry, ISBN: 0-85404-709-3.

Jover, E., Matamoros, V., Bayona, J.M. (2009). Characterization of benzothiazoles, benzotriazoles and bensosulfonamides in aqueous matrixes by solid-phase extraction followed by comprehensive two-dimensional gas chromatography coupled to time-of-flight mass spectrometry. Journal of Chromatography A, 1216, 40134019.

Janex-Habibi, M.L., Huyard, A., esperanza, M., Bruchet, A. (2009). Reduction of endocrine disruptor emissions in the environment: The benefit of wastewater treatment. Water Research, 43, 1565-1576.

Official Journal of the European Union. (2008). Annex 1. Environmental Quality Standards for Priority Substances and Certain Other Pollutants. L 348/92, 24.12.2008.

Miège C., Bados,P.,Brosse, C., Coquery, M.. (2009). Method validation for the analysis of estrogens (including conjugated compounds) in various aqueous matrices. Trends in Analytical Chemistry. 28, 2: 237-244

Ministère de l'environnement, Gouvernement du Québec (2003). Suivi des nonylphénols éthoxylés dans l'eau brute et l'eau traitée de onze stations de traitement d'eau potable au Québec. Par David Berryman, François Houdé, Christian Deblois, Margaret O'Shea. Disponible sur www.mddep.gouv.qc.ca. Envirodoq : ENV/2003/0001

Reemtsma, T. and Jekel, M. (2002). Organic Pollutants in the Water Cycle. Properties, Occurrence, Analysis and Environmental Relevance of Polar Compounds. Wiley-VCH, ISBN-10: 3-527-31297-8, page 148.

Semard, G., Bruchet, A., Cardinaël, P., Peulon, V., Bouillon, J.P. (2009). Comparison between conventional and comprehensive GC for the search of 58 target compounds and screening of undesirable pollutants in an environmental complex matrix. TECHNEAU: Safe Drinking Water from Source to Tap. Edited by Theo van den Hoven and Christian Kazner. ISBN: 9781843392750. . IWA Publishing, London, UK.

Ternes, T.A. and Joss, A. (2006). Human Pharmaceuticals, Hormones and Fragrances. The challenge of micropollutants in urban water management. IWA Publishing, Alliance House, 12 Caxton Street, London SW1H 0QS, UK, ISBN10: 1843390930.

Zenker, A., Schmutz, H., Fent, K. (2008). Simultaneous trace determination of nine organic UV-absorbing compounds (UV filters) in environmental samples. Journal of Chromatography A, 1202,64-74. 